\title{
Pedagogical Study into Tertiary Learning Styles in Vietnam
}

\author{
Barry Ramsay ${ }^{1}$
}

\begin{abstract}
Pedagogical studies for tertiary students in Vietnam are limited and no comparative benchmarking studies with other Asian tertiary students found. As a means to fill this gap and provide a better understanding the following study using Biggs (1987c) Study Process Questionnaire (SPQ), a 42-item self-report survey consisting of ratings on a 5 -point scale to questions relating to respondents' study motivations and their usual study patterns was conducted with 355 respondents. Findings were consistent with Hong Kong students and supports studies carried out in other countries by Kemper et al. (1989), Kemper and Gow (1991), Niles (1995), Volet and Renshaw (1996), Ramburuth (2001) and Hua, Williams and Hoi (2007). Despite learning in a "rote" manner during their formative years, students have adapted to deeper learning approaches although there is a still a slight but insignificant bias to surface learning. They desire to achieve and get good marks although strategy is limiting their progress. According to Biggs, this is commonly caused by a language problem.
\end{abstract}

Keywords: Pedagogy, student learning, study process questionnaire, Vietnam.

Available Online: 06-06-2016.

This is an open access article under Creative Commons Attribution 4.0 License, 2016.

\section{$1.0 \quad$ INTRODUCTION}

As a consequence of political economic pruning over recent decades, basic State institutions such as Police, Health and Education have suffered around the world. Universities have sought to make up the short fall in education funding predominately through fee-paying students. With this growth of commercialism in universities and opening the doors to a wider staunch of students the natural consequences is to draw from second and third-tier students to fill the gap left by the abdication of State responsibility. It is indeed this scenario that has spawned the resurgence in the teaching and learning movement.

Unfortunately the dilution of academic standards to cater for second and third-tier students who lack the same cognitive abilities as their processors is all but present today (Hayes, 2003; Furedi, 2004). On the $23^{\text {rd }}$ October 2008, the Times Higher Education reported serious concerns about "dumbing down" in universities so the debate continues (Gill, 2008). 
Historically the teaching and learning movement is typically an offshoot from the Education Faculty whose primary focus has been in the area of education and teaching within pre-schools, primary and the secondary domains. Tertiary education focuses in the main has been limited, historically due to lack of necessity from the high calibre of students entering higher learning universities. Since commercialism has superseded academic integrity and standards much of literature in teaching and learning movement has been towards teaching and less towards learning in the university environment.

\subsection{PRIOR RESEARCH}

Empirical research into tertiary student learning in Vietnam is scarce. Therefore, papers outside this jurisdiction, cultural and political environment were sourced to provide some insights from their particular perspective. Most I hasten to add have a heavy "Western" bias developed from their cultural, political and environmental ideology.

Whilst the theoretical and empirical research on learning styles in the UK, USA and Western Europe originated at the beginning of the 20th century (Coffield, Moseley and Hall, 2004) much has been generated as a results government restructuring, and refinancing of the tertiary sector that began in the 1990 s (Biggs, 2003).

Coffield, Moseley and Hall (2004) identified 71 models of learning styles since its inception and categorised 13 of these as major models. Many of the remaining 58 consist of rather minor adaptations of one of the major models (13) and therefore lack influence on the field as a whole. Some have been used only on very small or homogeneous populations, and yet others have been a brief fad but have long fallen into obscurity.

Interestingly one of the models of learning that was relegated by Coffield, Moseley and Hall (2004), was the Study Process Questionnaire (SPQ) used here in the primary research and the foundation of the teaching book 'Teaching for Quality Learning at University'. More locally the research in the field of tertiary student study and learning approaches have been investigated by Ramsden and Entwistle (1981); Biggs (1987c, 1991, 1992, 1993); Kember and Gow (1990); Phillips (1990); Niles (1995), Volet and Renshaw (1996), Ramburuth (1997, 2001) and Hua, Williams and Hoi (2007).

Some researchers (Phillips 1990; Biggs 1987c, 1991, 1992, 1993; Niles 1995, Volet and Renshaw 1996, and Ramburuth 1997, 2001) have looked at cross-cultural perspectives of student learning approaches, although most were mainly carried out in the "West" where international students are culturally adaptive due to the living environment and thus influenced or biased towards western ideology, Biggs $(1980,1991)$ being an exception.

Phillips (1990, p.722), suggests the following explanation for understanding "typical" learning differences between international students from Asian backgrounds and Australian students:

\section{Asian Student Perspective}

- Rote learning is common

- Non critical reception of information

- Students work hard to learn everything

- Students are inclined to seek clarification

- Few initiatives are taken

- A willingness to accept one interpretation

- Overall concepts are seen as important to

\section{Australian Student Perspective}

- Evaluative learning

- Critical thought is expected

- Students selectively learn the central concepts as well as detail

- Students are willing to seek assistance as part of the learning process

- Independent learning and research are rewarded

- Students are encouraged to apply general principles to specific situations and to test various interpretations

- Analytical thinking is encouraged. Students are 
understanding

Source: Adapted from Phillips (1990, p.722)

expected to support opinions with logical argument

However, researchers such as Phillips (1990) and Kember and Gow (1991), have questioned some of the generalisations and stereotypical descriptions from Phillips (1990) above, particularly those relating to the surface and rote learning practices of cross cultural students from Asian backgrounds, with Biggs (1990, p.1) drawing attention to the fact that:

"Considerable research gathered in Hong Kong, Australia, and other South East Asian countries suggests that the stereotype is based on a misunderstanding; Chinese students generally have a more 'academic' approach to learning (low surface, high deep) than Australians, while crosscultural studies show that Asians' attributions for academic success are more controllable, and therefore more amenable to intervention, than are those of Western students."

Biggs' contention has been supported by studies of the learning behaviour of Chinese students at Polytechnics in Hong Kong (Kember et al. 1989) which found no support for the notion of students from Asian backgrounds adopting essentially surface or rote approaches to learning. Through implementation of Biggs' SPQ (1987a), and comparisons with norms established for Australian CAE students, it was found that, overall, the mean scores of the Hong Kong students were similar to those of the Australian students, with the achieving and deep approach scores being higher for the Hong Kong students (Ramburuth, 2001).

Given the Asian dimension to learning styles, it was deemed more appropriate to adopt Biggs SPQ (1987a) method over Coffield, Moseley and Hall (2004) for comparative purposes.

\subsection{METHODOLOGY}

To provide a Vietnamese evaluation, this study used the Biggs' Study Process Questionnaire (SPQ), a 42item self-report survey consisting of ratings on a 5-point scale to questions relating to respondents' study motivations and their usual study patterns.

Using Biggs (1987a) research as a basis two (2) elements towards student approaches to learning were identified (1) motive and (2) strategy. He then identified three (3) approaches to learning, consisting of both a motive and strategy element as shown in Figure 1 below.

Figure 1: Construct of Biggs (1987a) six factor structure for Students approaches to learning

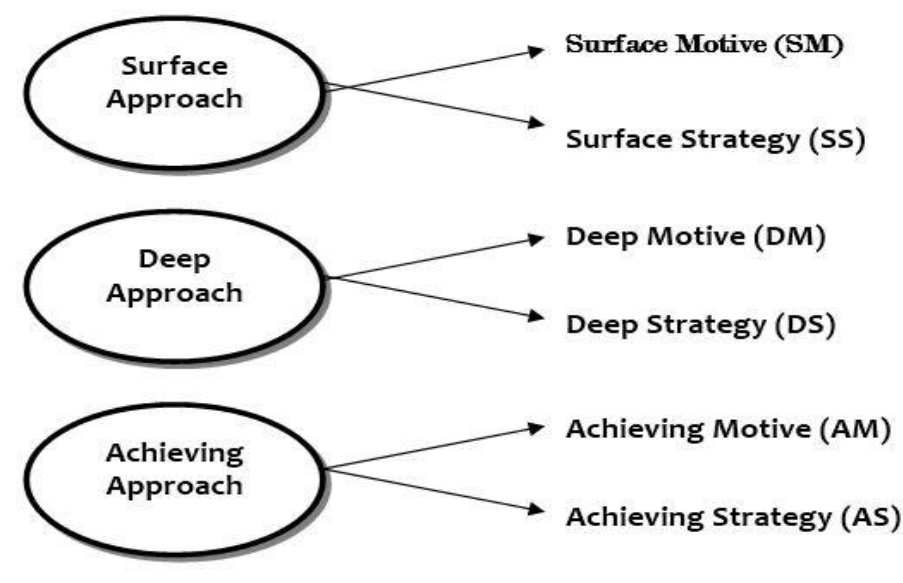

Surface Approach: The motive here is extrinsic; it is to carry out the task because of either positively or negatively reinforcing consequences. The student is willing to engage in learning tasks and pass minimally either because life will be even more unpleasant if he does not, or because he/she wishes to gain a paper qualification with minimal trouble or effort. Surface motivated students focus on what 
appear to be the most important topics (as defined by examinations) and aim to reproduce them. Because of this focus, they do not see interconnections between elements, or the meanings and implications of what is learned according to Biggs. (NUS 2006)

Deep Approach: The deep motive is based on intrinsic motivation or curiosity; the strategy arising from curiosity is to seek meaning. When a deep approach is adopted, there is a personal commitment to learning, which means that the student relates subject material to personally meaningful contexts or to existing prior knowledge, depending on the subject concerned. Deep processing involves processes of a higher cognitive level than rote learning searching for analogies, relating to previous knowledge, theorising about what is learned, and deriving extensions and exceptions. (NUS 2006)

Achieving Approach: Whereas the deep motive is focused on the process, the achieving motive is similar to the surface approach in that it is focused on a product, in this case the ego trip that comes from obtaining high grades and winning prizes. The general strategy is thus to maximise the chances of obtaining high marks. While this may lead to optimal engagement in the task (as does deep strategy), such engagement is the means, not the end (unlike deep strategy); the nature of the engagement really depends on what earns the most marks. (NUS 2006)

A self-selection method was used from a mixture of second (2) semester Bachelor of Commerce students and fourth (4) semester business Diploma students studying in an English environment in Vietnam. In total three hundred and fifty-five (355) valid responses were received and collated. SPSS v20 is used to perform the analysis. Respondents were advised about the objective and participation was voluntary and their identity would remain confidential.

\subsection{RESULTS AND DISCUSSION}

As a group, Vietnamese students studying in Vietnam in an English speaking "Western" institution exhibit a combination of all approaches at an above average level. Despite learning in a "rote" manner during their formative years, students have adapted to deeper learning approaches although there is a still a slight but insignificant bias to surface learning. They desire to achieve and get good marks although strategy is limiting their progress. According to Biggs, this is commonly caused by a language problem.

Derived profiles from subscale scores for the group

\begin{tabular}{lrrrr}
\hline Variable & Mean & SD & Decile & Symbols \\
Surface Approach & 57.43 & 12.54 & 10 & + \\
Surface Motive & 28.64 & 7.02 & 10 & + \\
Surface Strategy & 28.79 & 8.24 & 10 & + \\
Deep Approach & 54.64 & 9.70 & 9 & + \\
Deep Motive & 26.50 & 5.17 & 8 & + \\
Deep Strategy & 28.14 & 8.55 & 9 & + \\
& & & & \\
Achieving Approach & 52.00 & 7.80 & 10 & + \\
Achieving Motive & 27.79 & 4.39 & 10 & + \\
Achieving Strategy & 24.21 & 5.22 & 7 & 0 \\
n=355 & & & & + \\
\hline
\end{tabular}

Biggs (1987b) states:

"The experience of second language learning may encourage meta-learning, and the characteristics of deep-achieving, but if the second language is not secure, then achievement assessed in that language cannot be expected to be good: thus a good approach may be 
associated with poor performance. The ESL teacher, or the counsellor is the appropriate resource."

\subsection{CONCLUSION}

The research is consistent with Biggs (1987c) results from Hong Kong students although significantly higher Mean and Standard Deviation due to the small sample size (355), which is expected. It also supports studies carried out by Kemper et al. (1989), Kemper and Gow (1991), Niles (1995), Volet and Renshaw (1996), Ramburuth (2001) and Hua, Williams and Hoi (2007).

Whilst the sample size is limited to one institution in one location no further generalisations can be drawn other than more research is needed. Further research is definitely called for given the lack of empirical studies in Vietnam. Methodologies and interpretations in a culturally diverse environment may not have the same meanings between a "Western" and "Asian" perspective. It would therefore be a folly to suggest that "Western" ideology is the only measure of learning.

\section{REFERENCES}

Biggs, J.B. (1987a), Study Process Questionnaire, Australian Council for Educational Research, Melbourne.

Biggs, J.B. (1987b), Study Process Questionnaire Manual and Questionnaire, Australian Council for Educational Research, Melbourne.

Biggs, J.B. (1987C), Student Approaches to Learning and Studying, Australian Council for Educational Research, Melbourne.

Biggs, J.B. (1990), Asian Students' Approaches to Learning: Implications for Teaching and Learning, Keynote discussion paper, 8th Australasian Tertiary Learning Skills and Language Conference, 11-13 July, Queensland University of Technology.

Biggs, J.B. (1991), 'Approaches to learning in secondary and tertiary students in Hong Kong: some comparative studies', Educational Research Journal, Vol.6, pp.27-39.

Biggs, J.B. (1992), Why and How do Hong Kong Students Learn? Using the learning and study process questionnaires, Education Paper 14, Hong Kong: University of Hong Kong.

Biggs, J.B. (1996a), Approaches to Learning of Asian Students: A Multiple Paradox, In Asian Contributions to Cross-Cultural Psychology, Pandey, J (Ed.), Sage Publication: New Delhi, pp.180-199.

Biggs, J.B. (1996b), Learning, schooling, and Socialisation: A Chinese Solution to a Western Problem, In Growing Up the Chinese Way, Lau, S (Ed.), The Chinese University Press: Hong Kong, pp.147-167.

Biggs, J.B. (2003), Aligning teaching and assessment to curriculum objectives, (Imaginative Curriculum Project, LTSN Generic (entre), accessed 15 March 2016, <http://www.heacademy.ac.uk/resources.asp?process=full_record\&section=generic\&id=154>

Coffield, F. Moseley, D., Hall, E \& Ecclestone, K (2004), Learning styles and pedagogy in post-16 learning: A systematic and critical review, Learning and Skills Development Agency, accessed 15 March 2016, <www.lsda.org.uk/files/PDF/1543.pdf>

Furedi, F. (2004), Where have all the intellectuals gone? Continuum: London.

Gill, J. (2008), Keep it stupid, simple, Times Higher Education, dated 23 October 2008, accessed 2 April 2016, <http://www.timeshighereducation.co.uk/issuelndex.asp?issueCode=735>

Hayes, D. (2003), New labour, new professionalism, in: Satterthwaite, J, Atkinson, E and Gale, K (Eds) Discourse, power, resistance: challenging the rhetoric of contemporary education, Trentham Books: Stoke-on-Trent.

Hua, T.M. Williams, S and Hoi, P.S. (2007), Using the Biggs' Study Process Questionnaire (SPQ) as a diagnostic tool to identify "at-risk" students- a Preliminary Study, accessed 17 March 2016, < http://www.np.edu.sg>

Kember, D. and Gow, L. (1991), 'A Challenge to the Anecdotal Stereotype of the Asian Student', Studies in Higher Education, Vol.16, No.2, pp.117-128. 
Kember, D. Gow, L. Chow, R. Slaw, I. Barnes, P. and Hunt, J. (1989), 'Approaches to Study of Students Whose First Language is Not English', in Bickley, V. (Ed.), Language Teaching and Learning Styles Within and Across Cultures, Institute of Language in Education, Education Department, Hong Kong, pp.198-206.

National University of Singapore (NUS) (2006), NUS Students' Approaches to Learning and Studying, Centre for Development of Teaching \& Learning, dated 16 May 2006, accessed 15 March 2016, $<$ http://www.cdtl.nus.edu.sg/research/learnprofile.htm>

Niles, S. (1995), 'Cultural Differences in Learning Motivation and Learning Strategies: A Comparison of Overseas and Australian Students at an Australian University', International Journal of Intercultural Relations, Vol.19, No.3, pp.369-385.

Phillips, D.J. (1990), Overseas Students and Their Impact on the Changing Face of Professional Education in Universities, paper presented at the Australian Association for Research in Education Annual Conference: The Changing Face of Professional Education, Sydney University.

Ramburuth, P. (1997), Learning Style Preferences and Approaches to Learning of International Students Studying in Australia, Unpublished Doctoral Thesis, March.

Ramburuth, P. (2001), Cross Cultural Learning Behaviour in Higher Education: Perceptions versus Practice, presented at the Seventh International Literacy and Education Research Network (LERN) Conference on Learning, RMIT University, Melbourne, 5-9 July 2000, dated May 2001, accessed 10 April 2016, <http://ultibase.rmit.edu.au/Articles/may01/>

Ramsden, P. and Entwistle, N. (1981), 'Effects of academic departments on students approaches to studying'. British Journal of Educational Psychology, Vol.50, pp.368-383.

Volet, S.E., Renshaw, P.D. and Tietzel, K. (1994), 'A Short Term Longitudinal Investigation of Cross Cultural Differences in Study Approaches Using Biggs' SPQ Questionnaire', British Journal of Educational Psychology, Vol.64, pp.301-318. 